
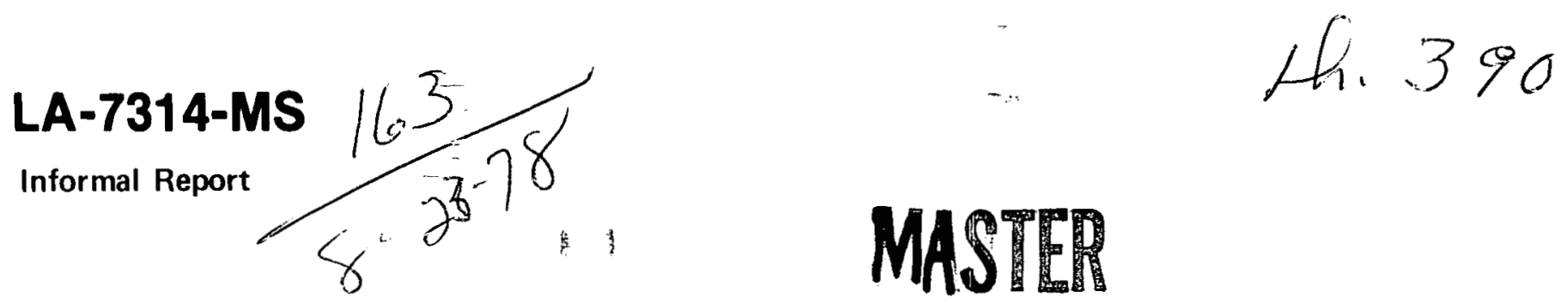

\title{
Safety Test of an Improved Multihundred Watt FSA: Launch Abort, Solid Propellant Fire
}

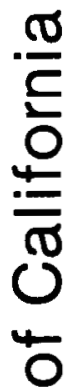

竞

文 


\section{DISCLAIMER}

This report was prepared as an account of work sponsored by an agency of the United States Government. Neither the United States Government nor any agency Thereof, nor any of their employees, makes any warranty, express or implied, or assumes any legal liability or responsibility for the accuracy, completeness, or usefulness of any information, apparatus, product, or process disclosed, or represents that its use would not infringe privately owned rights. Reference herein to any specific commercial product, process, or service by trade name, trademark, manufacturer, or otherwise does not necessarily constitute or imply its endorsement, recommendation, or favoring by the United States Government or any agency thereof. The views and opinions of authors expressed herein do not necessarily state or reflect those of the United States Government or any agency thereof. 


\section{DISCLAIMER}

Portions of this document may be illegible in electronic image products. Images are produced from the best available original document. 
An Affirmative Action/Equal Opportunity Employer

This work was supported by the US Department of Energy, Division of Advanced Systems and Materials Production.

This report was prepared as an account of work spansored by the United States Government. Neither the United States nor the United States Department of Enerrs, nur any it their employees. nor any of thetr contractors. subcontracters, or their emplovers, makes any warrantv. express or implied, or assumes any legal liabinity or responsibility for the accuracy. completeness, or usefulness or anv infwrmation. apparatus.

not infringe privately owned rights.

UNITED STATES DEPARTMENT OF ENERGY CONTRACT W-7408-ENG. 36 
LA-7314-MS

Informal Report

UC-71

Issued: July 1978

\title{
Safety Test of an Improved Multihundred Watt FSA: Launch Abort; Solid Propellant Fire
}

\author{
C. M. Seabourn
}

$$
\begin{aligned}
& \text { This report was prepared as an account of work } \\
& \text { sponsored by the United States: Government. Neither the } \\
& \text { United States nor the United States Department of } \\
& \text { Energy, nor any of their employees, nor any of their } \\
& \text { contractors, subcontractors, or their employees, makes } \\
& \text { any warranty, express or implied, or assumes any legal } \\
& \text { liability or responsibility for the accuracy, completeness } \\
& \text { or usefulness of any information, apparatus, product or } \\
& \text { process disclosed, or represents that its use would not } \\
& \text { infringe privately owned rights. }
\end{aligned}
$$

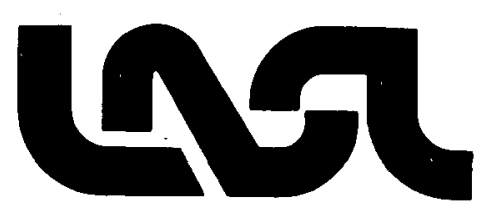




\title{
SAFETY TEST OF AN IMPROVED MULTIHUNDRED WATT FSA:
}

\author{
LAUNCH ABORT, SOLID-PROPELLANT FIRE
}

by

C. M. Seabourn

\begin{abstract}
This safety test consisted of exposing a simulant-fueled Improved Multihundred Watt Fuel Sphere Assembly, containing a Pt-3008 sphere holding the fuel simulant, to a single proximity fire of UTP-3001 solid rocket propellant for $10.5 \mathrm{~min}$. The graphite outside shell sustained only minor abrasion damage. It was covered on one side with a heavy deposit of alumina from the fire mixed with silica from the test bed. The Pt-3008 shell had small amounts of carbon, alumina, and silica deposited on its surface but sustained no other damage. The Pt-3008 sphere was not breached, and therefore the fuel sphere assembly would not release fuel in a solidpropellant fire of a launch abort.
\end{abstract}

\section{INTRODUCTION}

As a part of the evaluation of $\mathrm{Pt}, 30 \mathrm{wt} \% \mathrm{Rh}, 8$ wt\% W alloy (Pt-3008) developed by Oak Ridge National Laboratory as a containment material [postimpact containment shell (PICS)] for $\mathrm{PuO}_{2}$ radioisotopic heat source fuel for the Improved Mul. tihundred Watt heat source, a modified Multihundred Watt (MHW) Fuel Sphere Assembly (FSA) was exposed to a single proximity fire of UTP-3001 solid rocket propellant. The FSA is composed of the PICS containing the radioisotopic fuel placed inside a graphite impact shell (GIS) (Fig. 1). Replacing the standard irridium shell with Pt-3008 is desirable because Pt-3008 is less expensive and easier to fabricate. The test described in this report was carried out to see if a Pt-3008 PICS, which has a melting point some $400^{\circ} \mathrm{C}$ lower than that of iridium, inside a GIS could survive exposure to the intense heat of the solid-propellant fire.

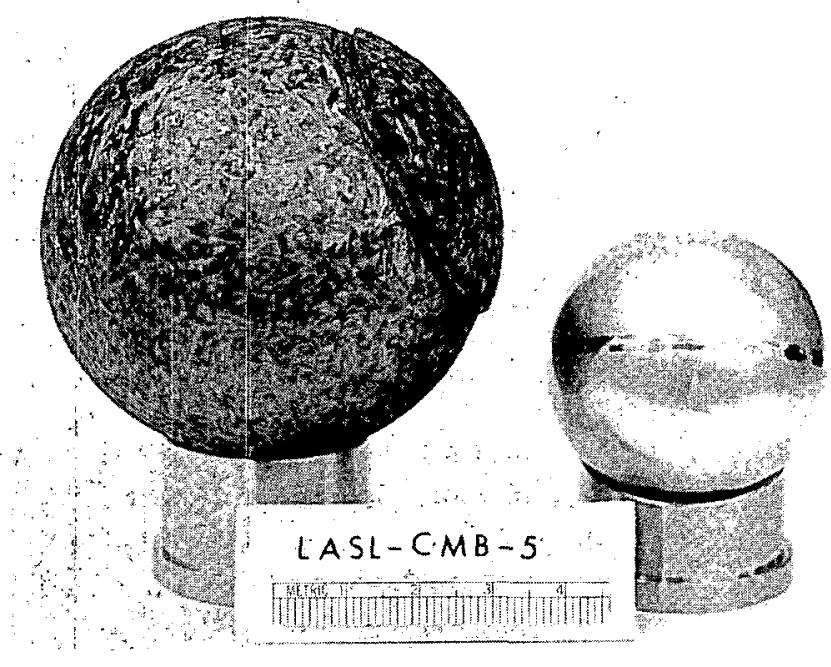

Fig. 1.

As-received GIS and PICS for assembly as an FSA. 


\section{TEST DESCRIPTION}

\section{A. Test Specimen}

A single FSA (PICS T-4 inside GIS S/N 936819-2) was used for the test. It was fabricated by Monsanto Research Corporation's Mound Facility (Miamisburg, Ohio) according to the standard MHW procedures, except that the $\mathrm{PuO}_{2}$ fuel was replaced with a $\mathrm{ThO}_{2}$ (thoria) simulant and the standard iridium shell was replaced with one made of Pt-3008. The data furnished with the FSA are given in the Appendix. The as-received specimen is shown in Figs. 1 and 2. The FSA was sent to us disassembled to facilitate our pretest inspections. There were no anomalies visible and none were detected by radiography; so the Pt-3008-clad thoria was inserted in the GIS, and the cap was screwed in place to form the FSA.

\section{B. Propellant}

The solid rocket propellant used for this test was a piece of U'TP-3001 propellant 91.4 by 91.4 by 104.1 $\mathrm{cm}$ ( 36 by 36 by $41 \mathrm{in}$.). This is the propellant that is used in the Solid Rocket Motors of the Titan IIIE, and it is quite similar to the propellant that will be used for the NASA Space Transportation System (STS) launch vehicle. The propellant was inhibited with Versamid $125^{*} /$ Epon $815^{* *}$ epoxy on five sides and placed on a sand bed with the uninhibited 91.4by $91.4-\mathrm{cm}$ face vertical for the test. The propellant was inhibited on all surfaces not facing the FSA test item so that a maximum-duration fire would be obtained to simulate the period during which a large piece of a motor segment would burn.

\section{Test Setup}

The test setup is shown in Fig. 3. A tube furnace with a servo-operated door, for preheating the FSA in an air atmosphere, was suspended vertically from the metal stand. Bslow the furnace was an inclined metal trough that, upon initiation of the test, would carry the released FSA to the base of the un-

*General Mills Chemicals, Inc., Minneapolis, MN 55435.

**Shell Chemical Co., Houston, TX 77001.

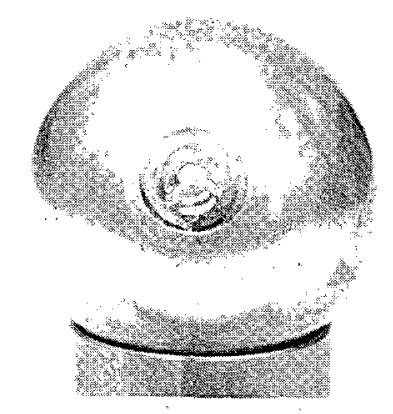

$L A S L-C M B-5$

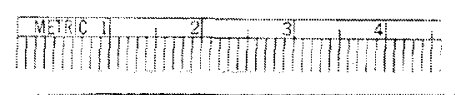

Fig. 2.

As-received PICS showing one vent.

inhibited face of the propellant. The Transite* board seen in Fig. 3 leaning against the propellant face was used only before test initiation to prevent possible contact of the hot FSA with the propellant in the event of a premature FSA release. Immediately before test, this Transite board was removed. A hot-wire-initiated pyrotechnic igniter was affixed to the surface of the propellant. A bank of sand was built up behind the propellant to prevent tip-over of the propellant during the test.

Five W-26 Re/W-5 Re thermocouples encased in thoria tubes were placed near the ground level in front of the burn face of the propellant (Fig. 4). These thermocouples were connected to strip-chart recorders so that continuous records of temperature during the fire test could be obtained.

\section{Test Operation}

The furnace containing the FSA was heated to the $1020^{\circ} \mathrm{C}$ test preheat temperature in $1.5 \mathrm{~h}$. This temperature was maintained by regulation of input power for $30 \mathrm{~min}$ to assure uniform temperature of the FSA. The furnace temperature was monitored by two thermocouples.

To initiate the fire test, the furnace door was activated, releasing the FSA. The FSA fell to the inclined metal trough (Fig. 3) and rolled down to the ground in front of the propellant, touching the

\footnotetext{
*Johns-Manville Corporation, Denver, CO 80217.
} 


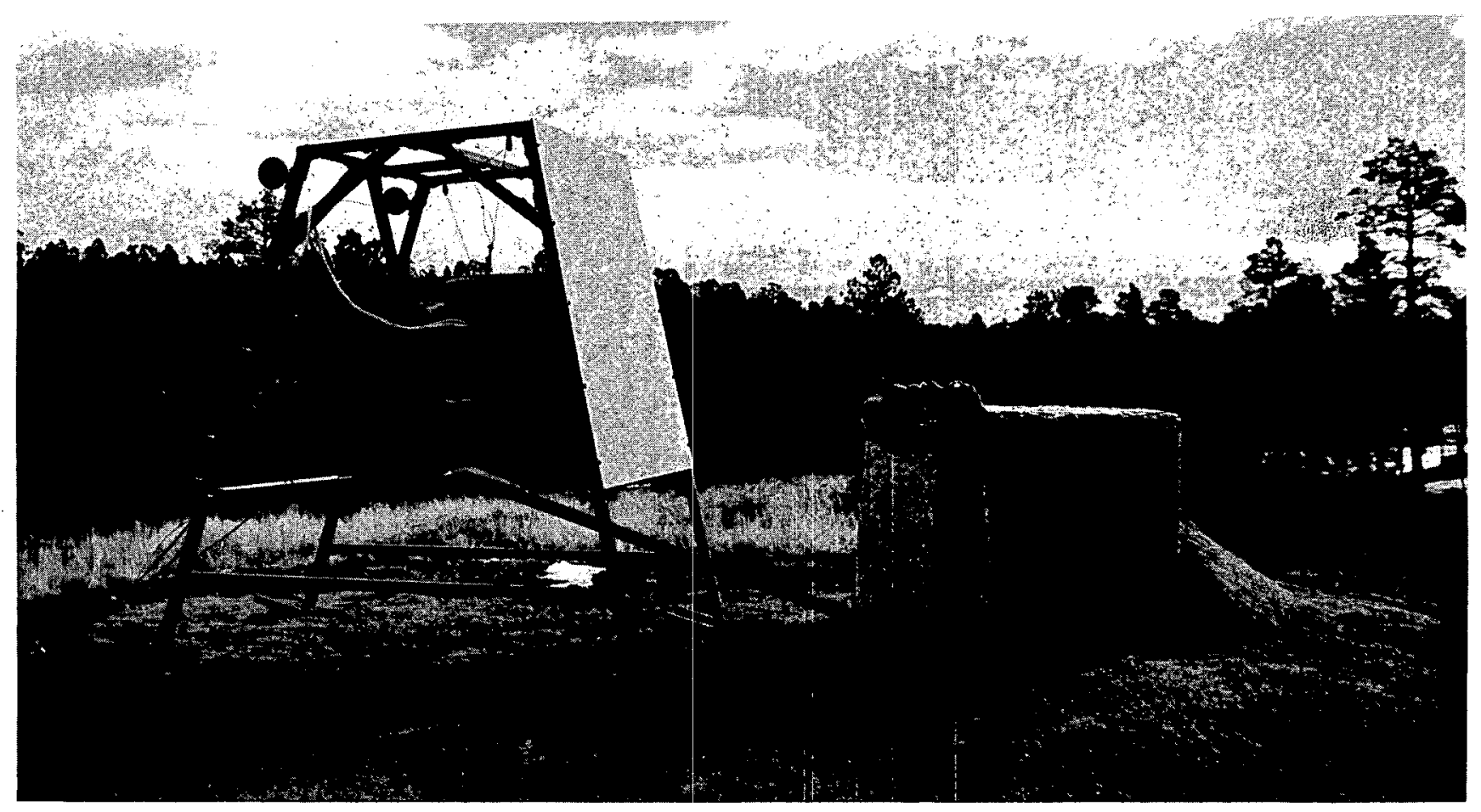

Fig. 3.

Test setup for propellant fire test.

propellant surface. On contact, the propellant ignited; however, to assure uniform ignition, the pyrotechnic igniter was initiated. Simultaneously, the metal structure holding the furnace was dragged $\sim 5 \mathrm{~m}$ away from the ignited propellant by attached cables running to a pole (visible behind the furnace assembly in Fig. 5), then to a remotely operated winch. The propellant burned evenly and without incident for $10.5 \mathrm{~min}$. High-speed movies were made of the burn.

Figure 5 shows the posttest condition of the test area. The arrow indicates the tested FSA. Figure 6 is a close-up view of the FSA showing the $1.5-\mathrm{cm}$-thick deposit of alumina and silica on the side of the FSA that had faced the burning propellant.

Temperatures measured by the thermocouples during the test are given in Table I. The maximum temperature experienced by the thermocouples and, therefore, by the FSA was $2060^{\circ} \mathrm{C}(\mathrm{T} / \mathrm{C} 1)$ at the beginning of the test. As the burning surface of the propellant receded from the FSA and the thermocouples, the observed temperature declined.

\section{POSTTEST RESULT}

Minor damage including some flaking of the graphite, was sustained by the outer surface of the FSA. Radiographs of several orientations of the FSA indicated that there was no detectable damage to the PICS. The cap of the GIS could not be unscrewed, so the GIS was cut open. Figures 7 and 8 are photos of the PICS showing a carbon image from the GIS (Fig. 7) and a ring-shaped deposit around a band where the GIS cap threads had been (Fig. 8). There was no observable damage to the vents (Fig. 8). From the information in Ref. 1, we concluded that the ring-shaped deposit was alumina from the propellant fire and silica from the sand test bed that had penetrated the GIS cap threads.

The PICS was dissected at a $30^{\circ}$ angle to the weld. There was no observable damage to either the interior surface of the PICS or to the thoria fuelsimulant sphere (Fig. 9).

Photomicrographs of sections of the two hemispheres and welds are given in Figs. 10-12. The 


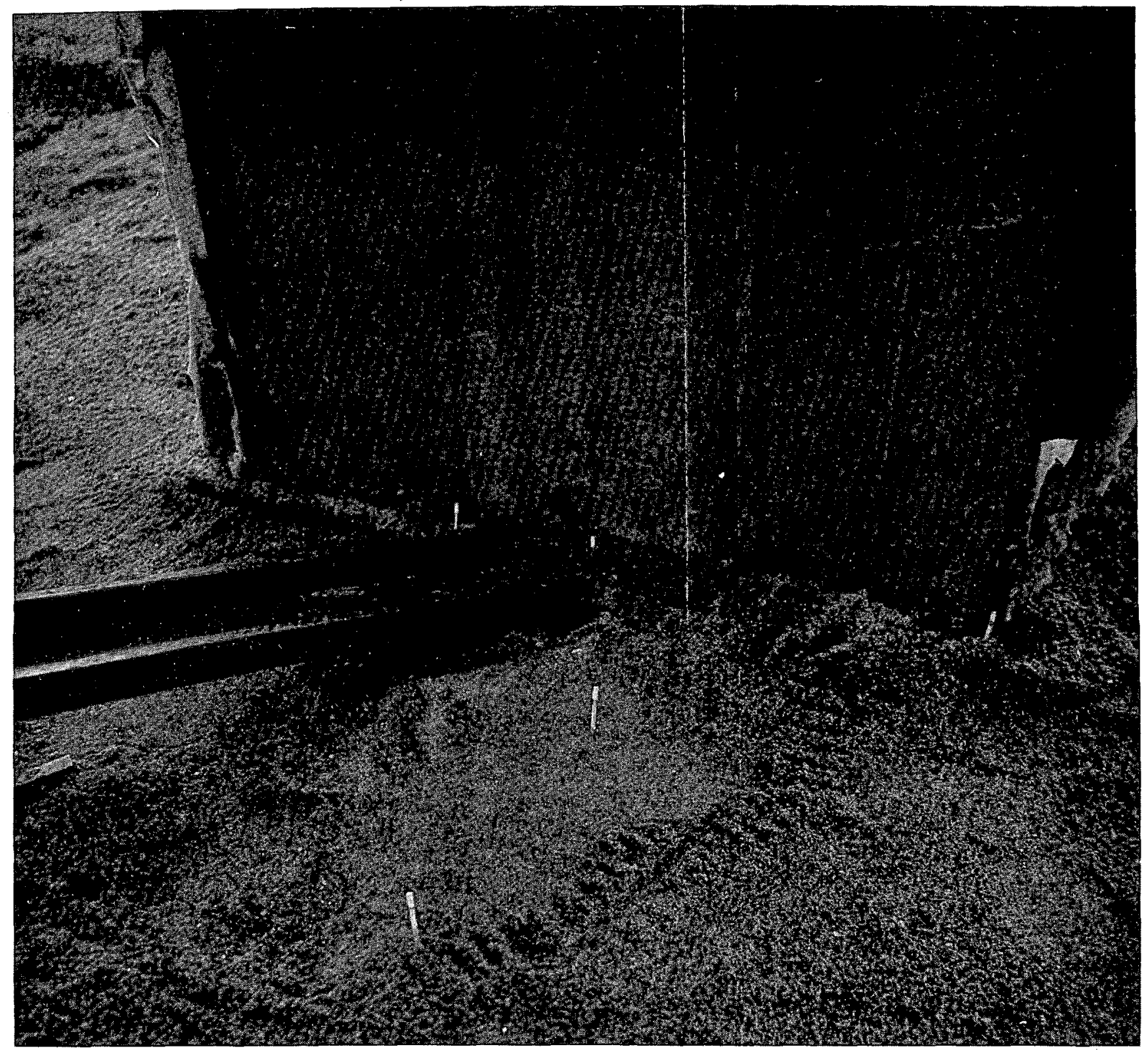

Fig. 4.

Test setup showing thermocouple placement.

grain structure in all photos appears normal, thus the structure was apparently not altered by the fire test. There was no evidence of chemical reaction or eutectic formation by the carbon, alumina, or silica deposits on the PICS surfaces.

\section{CONCLUSIONS}

A thoria-fueled, Pt-3008 PICS of an FSA did not fail when it was exposed to a 10.5-min UTP-3001 fire. There was no evidence of any but the most 


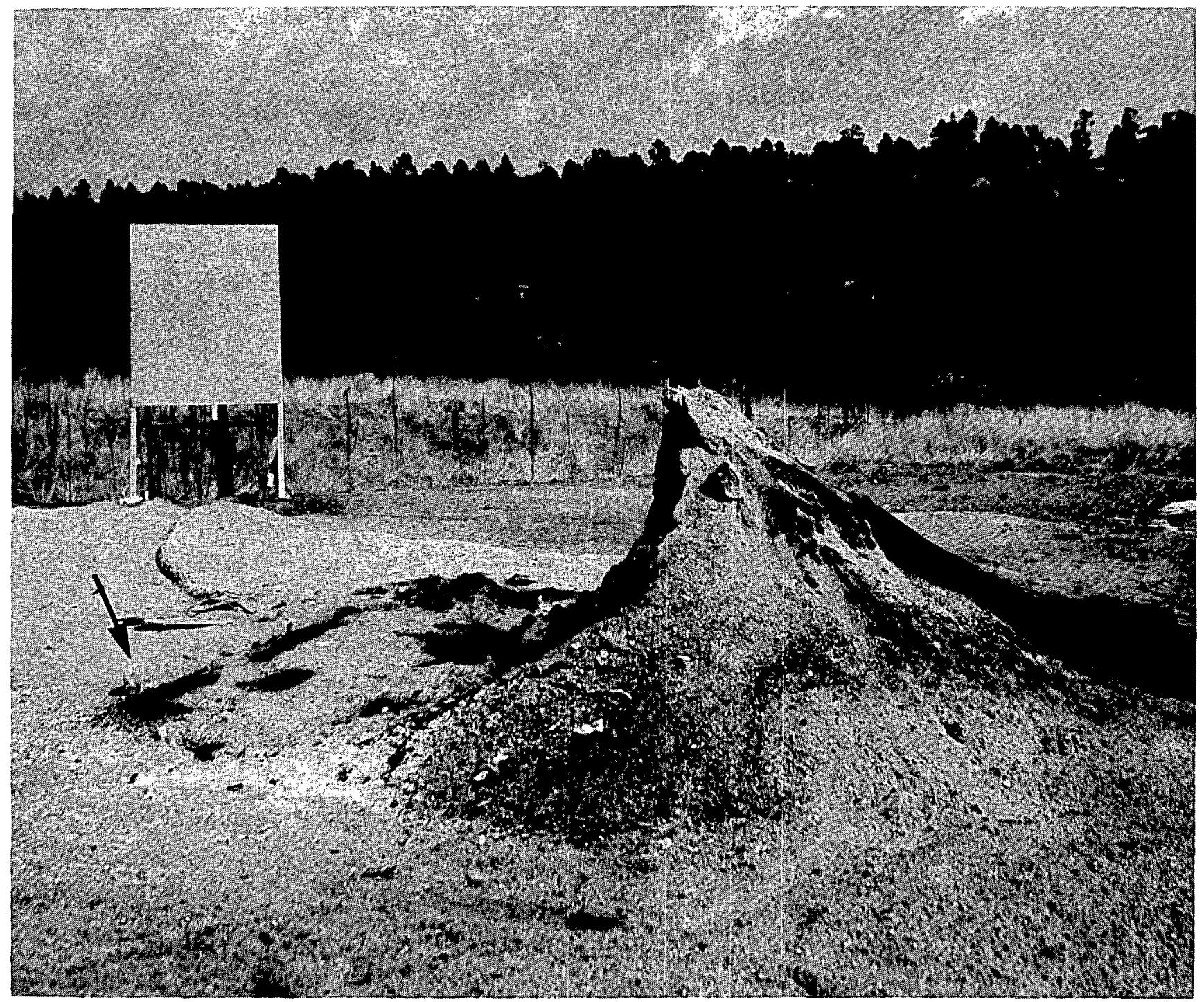

Fig. 5.

Posttest view of the test site.

superficial changes in the condition of the FSA components after the fire. Thus, it appears that a Pt3008 PICS of an FSA will survive a maximumlength single proximity UTP-3001 fire such as might occur in a launch abort of the Titan or STS launch vehicle. Probably, the Pt-3008 PICS inside a GIS could survive much larger single proximity fires without failure. It would not be expected to survive in the absence of the GIS, however, because the iridium cladding does not. ${ }^{1}$

\section{ACKNOWLEDGMENTS}

I wish to thank N. K. Kernodle and the support personnel of WX-3 for their diligence and ingenuity in the fabrication of the test setup and the performance of this test. I also thank F. W. Schonfeld for the metallography for this test. 


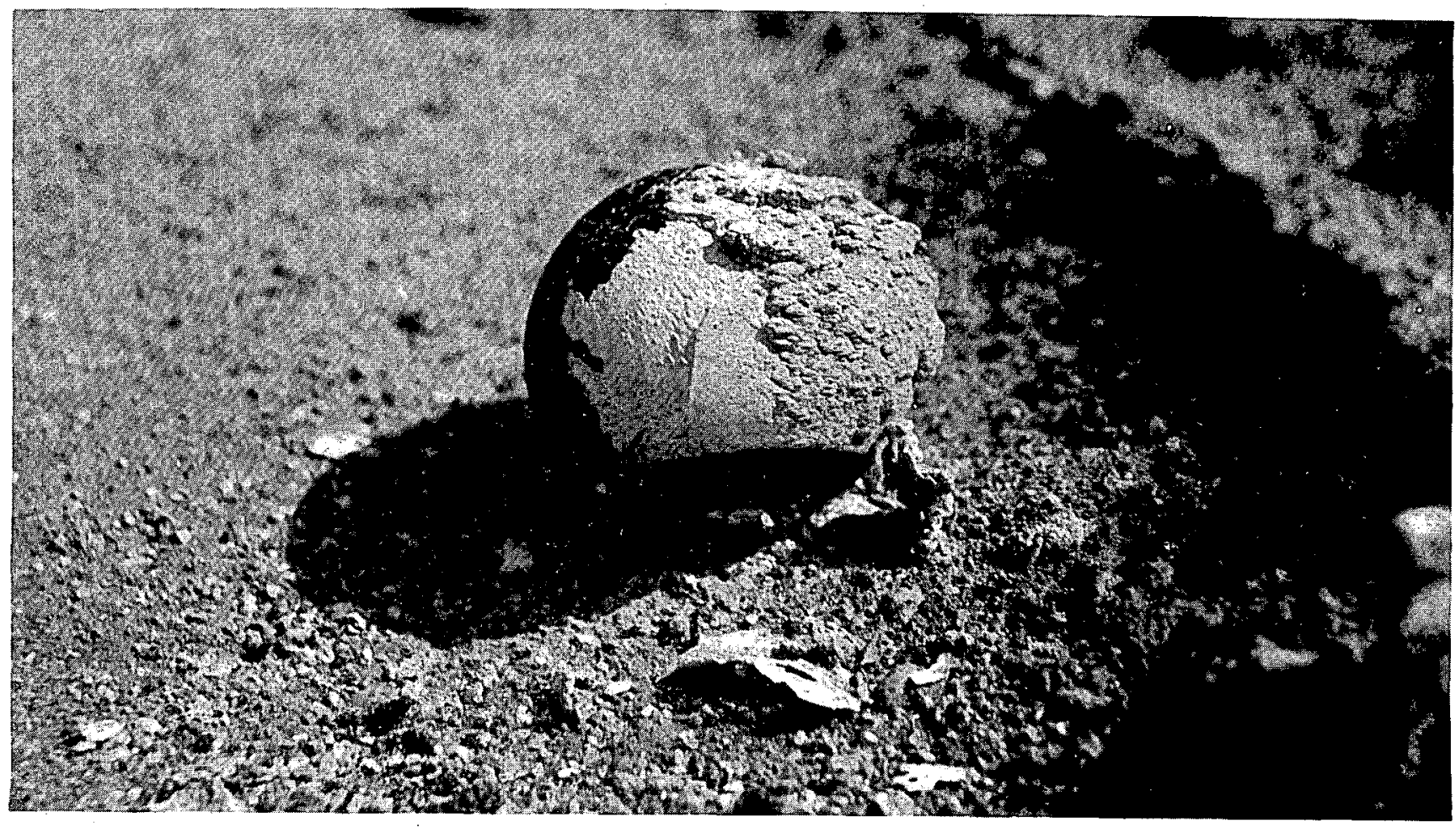

Fig. 6.

Posttest close-up of the FSA.

TABLE I

TEMPERATURE HISTORY OF PROPELLANT BURN ${ }^{a}$

\begin{tabular}{|c|c|c|c|c|c|c|c|c|c|c|c|c|}
\hline Time (min) & $0.25^{b}$ & 1 & 2 & 3 & 4 & 5 & 6 & 7 & 8 & 9 & 10 & 10.5 \\
\hline $\mathbf{T} / \mathbf{C}^{\mathrm{c}}$ & & & & & & & & & & & & \\
\hline 1 & $2060^{\mathrm{d}}$ & 1660 & 1638 & 1632 & 1610 & 1604 & 1552 & 1454 & Failed & -- & -- & \\
\hline 2 & Failed & -- & -- & -- & -- & -- & -- & -- & -- & -- & -- & \\
\hline 3 & 1827 & 1827 & 1827 & 1510 & 1499 & 1499 & 1499 & 1499 & 1499 & 1499 & 788 & 32 \\
\hline 4 & 2038 & 1816 & 1232 & 1760 & 1427 & 1538 & 1538 & 1454 & 1316 & 982 & 816 & 4 \\
\hline 5 & 2038 & 1982 & 1927 & 1454 & 1343 & 1260 & 1371 & 1427 & 954 & 482 & 288 & 21 \\
\hline
\end{tabular}

aPropellant was 91.4 by 91.4 by $104.1 \mathrm{~cm}$.

-Time of maximum temperature.

'Thermocouple locations:

1. $1.25 \mathrm{~cm}$ from base of propellant surface (near FSA), center.

$2.1 .25 \mathrm{~cm}$ from base of propellant surface, center.

$3.1 .25 \mathrm{~cm}$ from base of propellant surface, edge.

4. $30.5 \mathrm{~cm}$ from base of propellant surface, center

5 . $61 \mathrm{~cm}$ from base of propellant surface, center.

dTemperatures in degrees Celsius. 


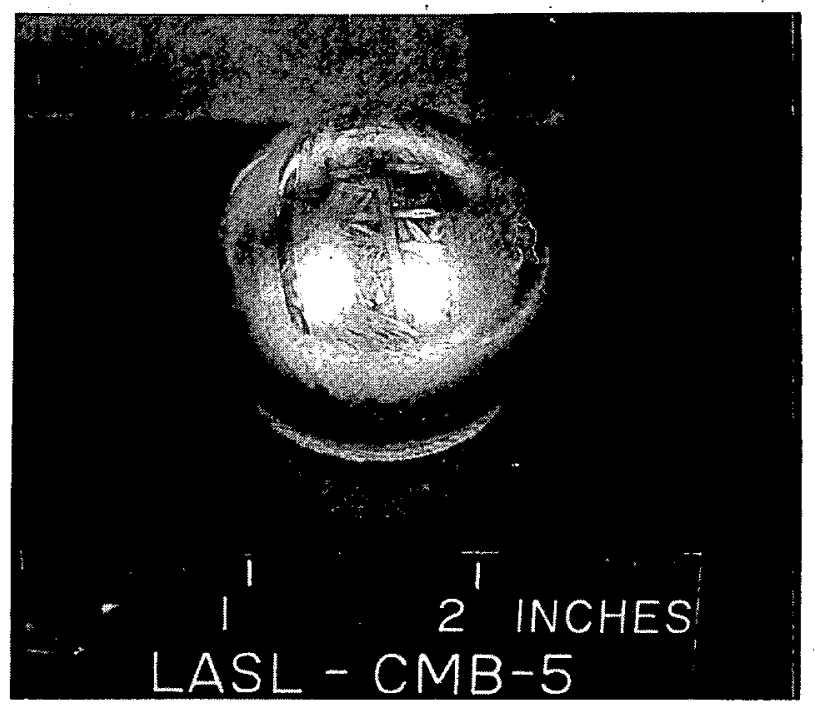

Fig. 7.

Posttest view of the PICS showing graphite imprint from the GIS.

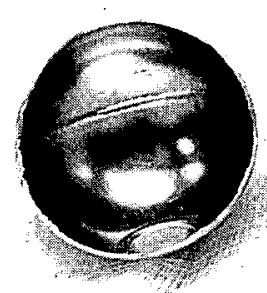

A

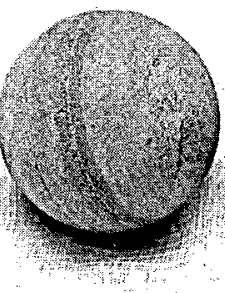

Fig. 9.

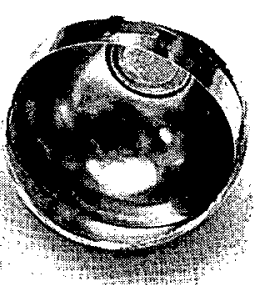

B

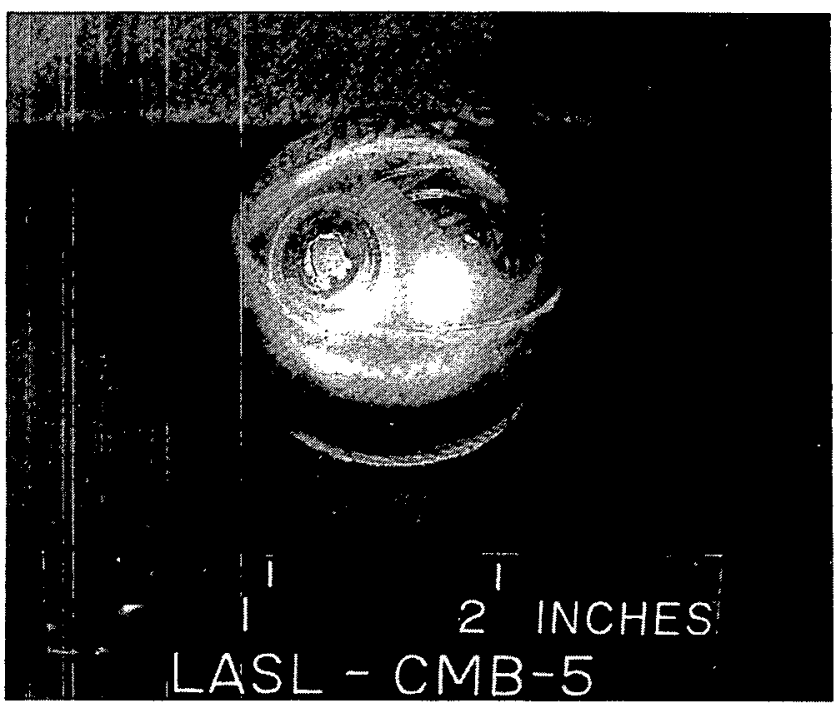

Fig. 8.

Posttest view of the PICS showing the vent and the ring deposit on the surface.

\section{REFERENCE}

1. E. C. Snow, "Safety Test No. S-6, Launch Pad Abort Sequential Test Phase II: Solid Propellant Fire," Los Alamos Scientific Laboratory report LA-6034-MS (August 1975).

Interior of dissected PICS with thoria fuel simulant sphere. 


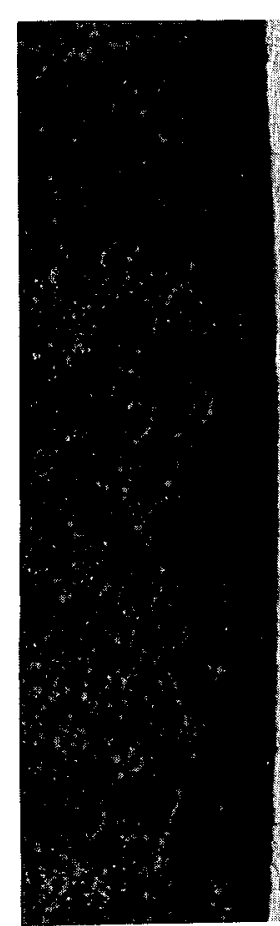

(a)

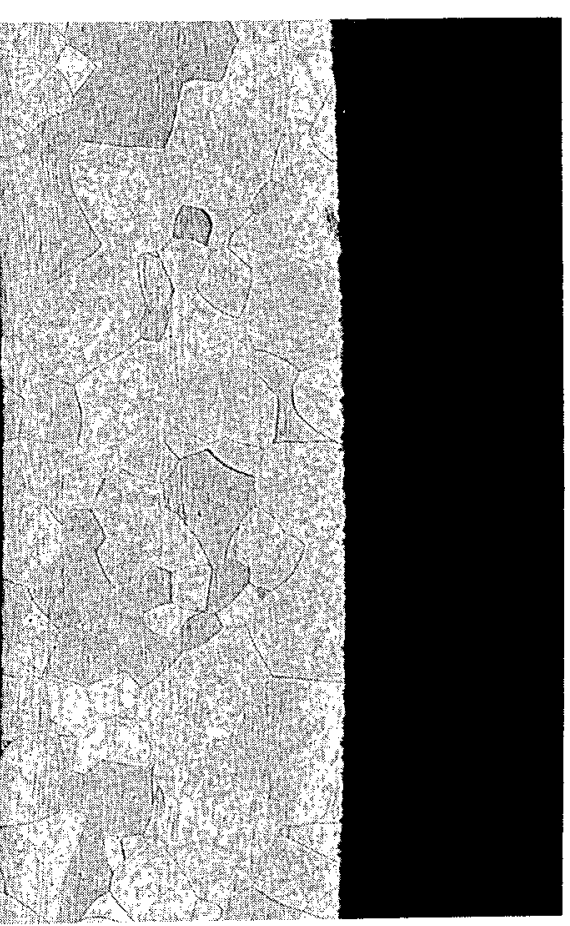

(b)

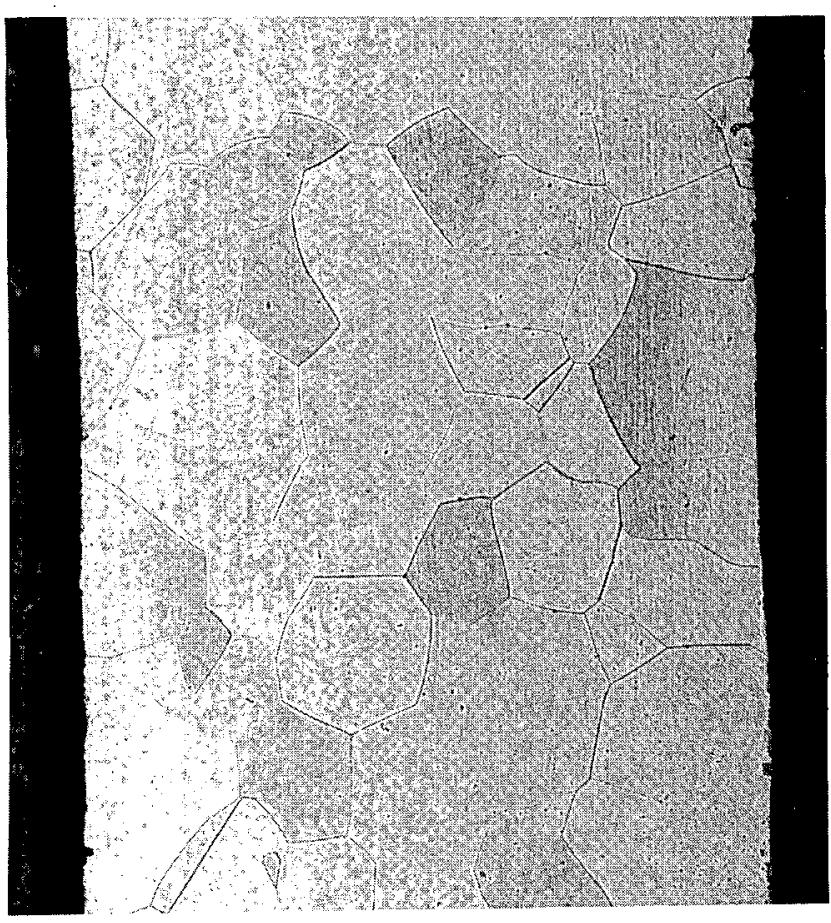

(b)

Fig. 10.

Wall section of hemisphere A of the PICS at (a) 50X and (b) 100X.

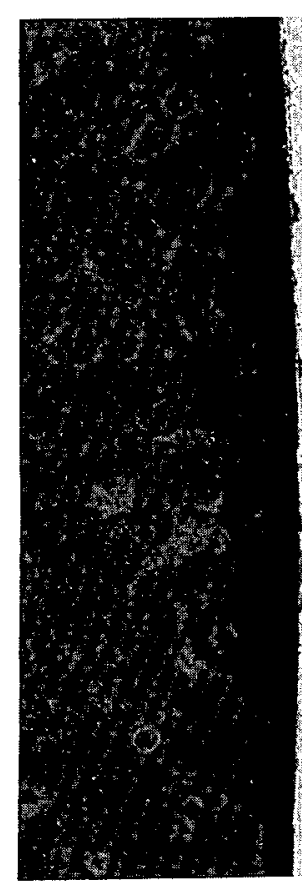

(a)

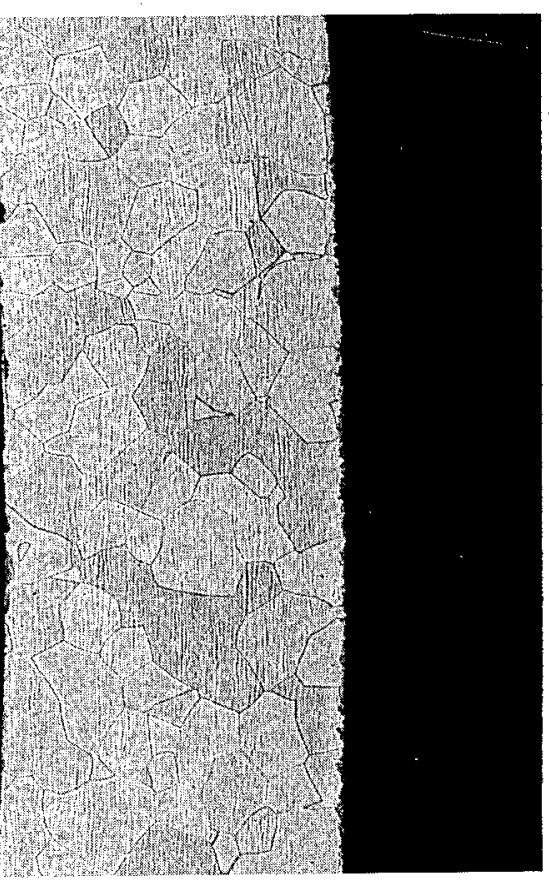

(b)

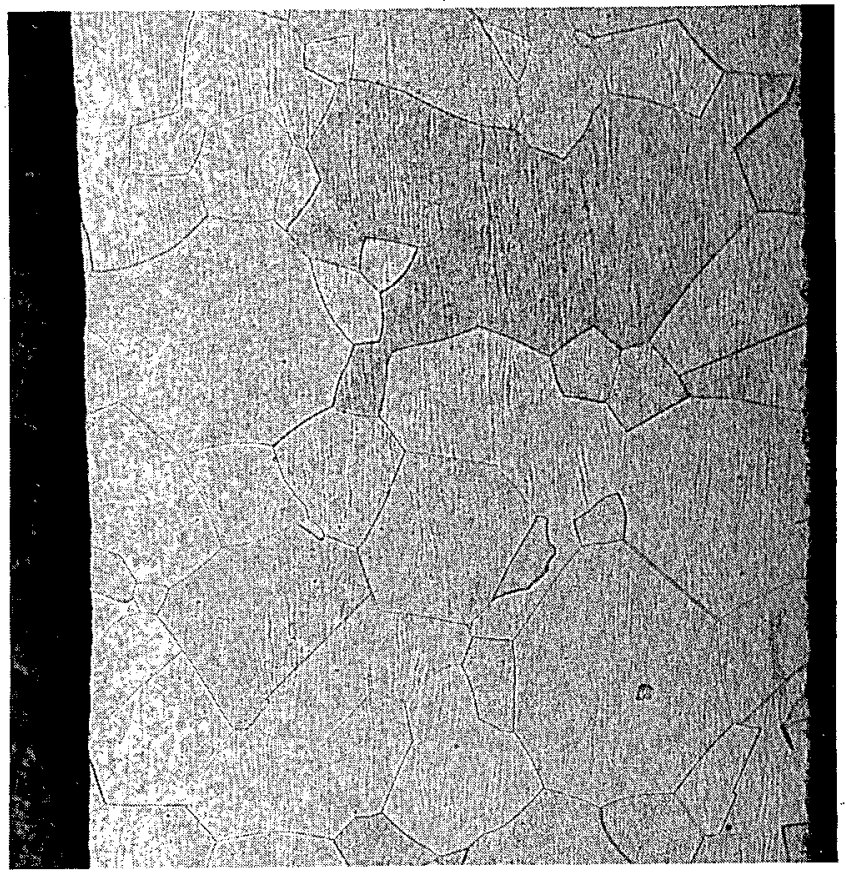

Fig. 11.

Wall section of hemisphere $B$ of the PICS at (a) $50 X$ and (b) $100 X$. 

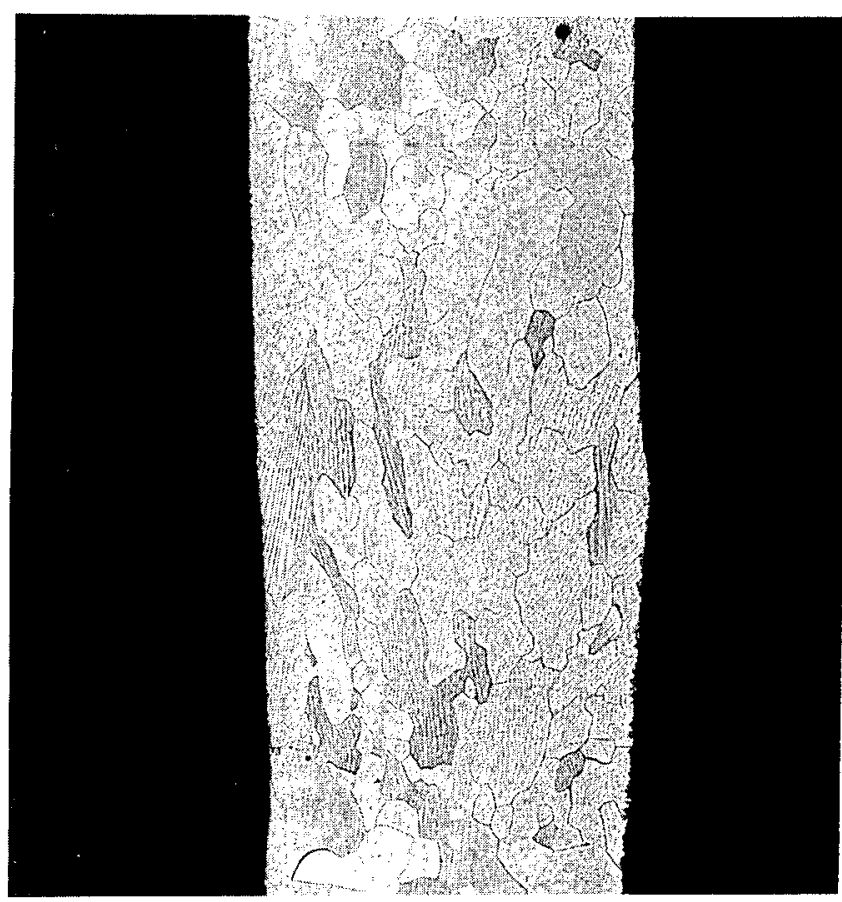

(a)

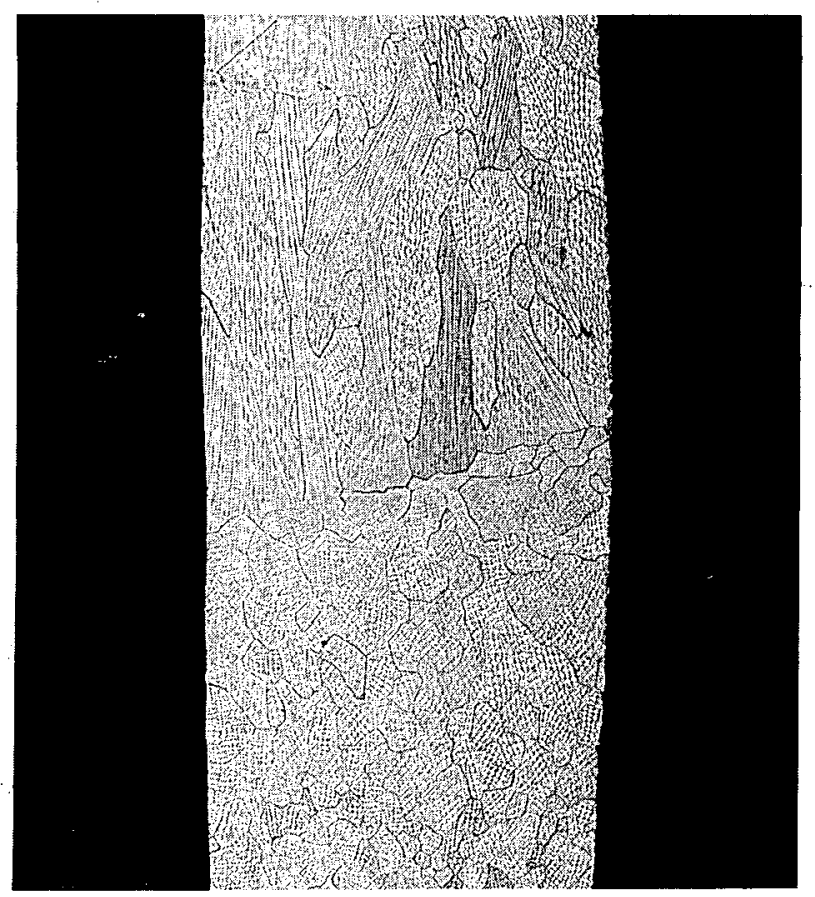

(b)

Fig. 12.

Weld sections of the PICS at 50X. (a) hemisphere $A$ and (b) hemisphere $B$. 


\title{
APPENDIX
}

\section{DATA PACKAGE FOR SIMULANT-FUELED FSA}

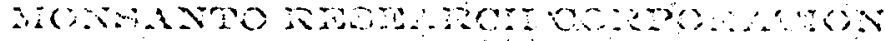 \\ s.men locaiton : Tardiare Fabrication \\ aare : November 15, 1977 \\ suwar : Pt-3003 Wald Shieids and Decon Covers \\ Etsasis: : \\ io : E. W. Johnson
}

Approximately thirty-six square inches of 5 mil pt-3008 foil sericilized EzX-4B-i was received from Battelle-Columbus for use in fabricating weld shields and decon covers. This as-received material exnibited a wrouchit nicrostructure aiti a microhariness average (edge-center-edge) $0 \tilde{i}$ OFH-430.

Eight weld shields and forty decon cover forming discs were blarked fiom this material. The forty discs ware then haat traated (reciysta?lizad) for one hour at $1100^{\circ} \mathrm{C}$ in vacuo. A metallographic sampla indicated the discs were fully recrysiallized, exhibited a grain size of ASTM-3, and a miciohardness average $0 i$ OPH-251. It should also be roted that no cracks or delaninations were obseryed in ejthar the wrought or recrystallized metaliographic samples.

The discs liere then formed into decon covers and processed per MD-701E], Operation 6 , (Formirg of Iridium Decon Covers). However, the cieaning procedures deviated in that this hardware was acid cleened in a 50:50 water-hydrochloric acid solution. The firal production yield was $45 \%$ or 13 of 40 parts. Twenty were rejected for come dye indications and two for dimensionai anomalies. hitrough the material was fully recrystallized, it did not possess adequate ductiiity at room temperature.

The eight weld shields were processed per M-70101, operation No. 5, (Forming of Iridium Weld Shieles). There were t:10 procoss deviations however, one in cleaning ard one in outgassing. The acid clean ccnsisted of 50:50 waterhydrochloric acid soiution and the hardware was heat treated (outgassed) for one hour at $1200^{\circ} \mathrm{C}$ in vacuo. Inadequate cictility at room temperature contributes. to exireme difficulty in forming the :eld shields on tine roil fixiure. ine material work hardens rapidly and exhibits strois springback action.

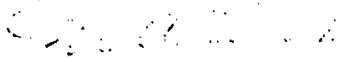

Don A. Pawlak

OAP:Eg 


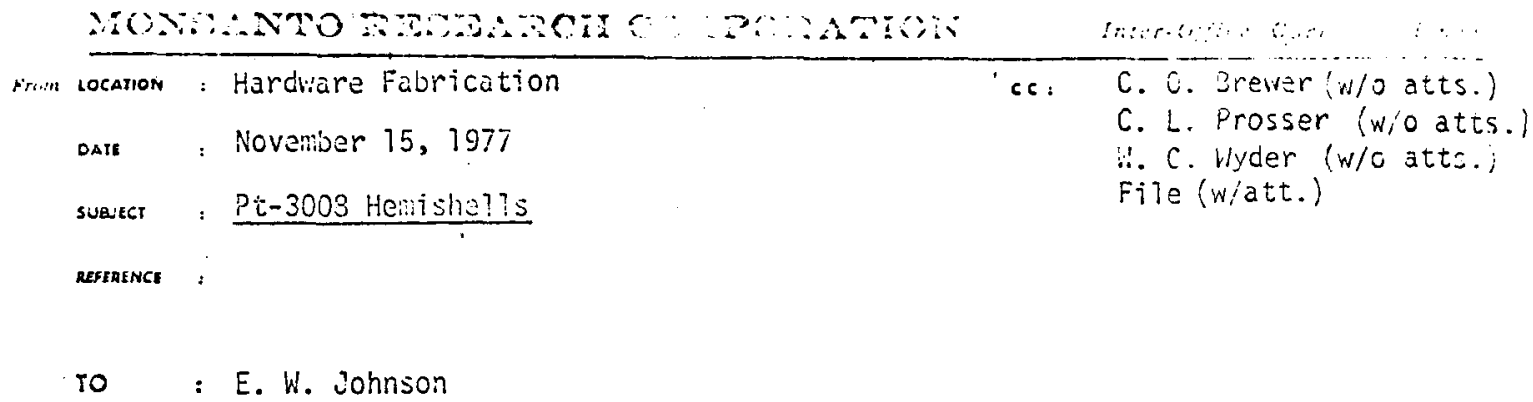

This memo is written to document the reprccessing of four Pt-3003 hemishells serialized LCPT-26-1;20-2;20-3; and 26-4. These shalls were supplied to MRC by ORNL for weld development and faorication into impact test units.

Initially, the hemishells were solvent and acid cleaned; the latter being a 50:50 water-hycirochloric acid solution. However, this cleaning followed reweighing, repackaging, and identity verification. Tha hemishells were then hect treated (recrystallized) for one hour at $1050^{\circ} \mathrm{C}$ in vacuo. After recrystallizing, thay :.ere precharged and sized on 0.775 -inch spherical radiused punch through a 1.602-inch diameter hardened steel die.

They were then sent to the Machine Shop for EDM vent holes in the poles ard Japping of the eạuator to give a flat surface. A dye penetrant and compleced gage lab inspection followed; however, the reprocessed hemishells were still out of hound but were pairable and required orientation marks. See Gage Repori No. 107692 dated October 14, 1977.

After the orientation marks were grit blasted on the paired hemishells, they were again solvent and acid cleaned and heat treated (outgassad) for one hour at $1200^{\circ} \mathrm{C}$ in vacuo. They were then sent to Material Control and transferred to the weld group for subassembly along with four additional hemishells which were reprocessed in July of 1975 . These snells were also solvent and acid cleaned and were serialized LCPT-22-4; 25-2; 25-4; and 27-3.

It should be noted at this point, however, that two hemishells (LCPT-26-1 and 26-4) were not acceptable (dye penetrant inspection) in accordance with sraning No. 1-14944. Further examination indicated that hemishell reyors vas initeasible, since wall thickness would be significantiy reduced because of apparent indication deptis. Subsequently, it was recommended that this paired set of hemishells be restricted to weld development. 
It is also significant to note thit two of the 1975 peprocessed hemishells (LCPT-22-4 and 27-3) were a?so considered rot acceptable following dye penetrant inspection. Subsequent?y, the approrirate dye inspection reports are attached.

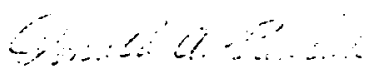

Donald A. Pawlak

DAP:eg

Attaciments 


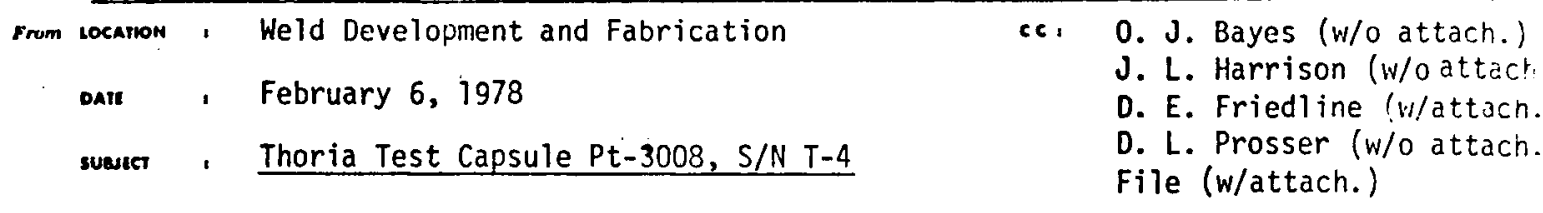

astaknet :

ro : E. W. Johnson

As part of the Improved MHW Heat Source Program, MF was requested to encapsulate three Pt-3008 Pu-238 heat sources and one Pt-3008 $\mathrm{ThO}_{2}$ test capsule from four sets of $\mathrm{Pt}-3008$ hardware. One complete set of hardware was designated for electron beam subassembly weld development with no destructive testing to be performed on the subassembly welds. This development set of hardware was used to fabricate Test Capsule Pt-3008 T-4.

The following is a record of assembly of that test capsule:

A1) welds were made using the MHW fixtures. The electron beam weld parameters were adjusted to accommodate the difference in the melting temperature of the platinum alloy versus iridium. The GTA weld was made per marked-up Operation Sheet MD-70161, No. 18, (attached).

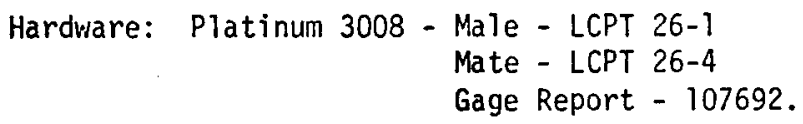

Hardware: Platinum 3008 - Male - LCPT 26-1

Mate - LCPT 26-4

Gage Report - 107692.

Thoria Sphere - S/N 930 (outgassed 2 hours, $1000^{\circ} \mathrm{F}$, at $10^{-5}$ torr).

The subassembled hardware was transferred to the "cold" MHW inert gas weld box. The hardware was assembled using MHW weld fixturing and welded per Operation Sheet MD-70161, No. 18. The PISA was welded in a helium atmosphere with the following impurities: $<30 \mathrm{ppm} \mathrm{O}_{2},<500 \mathrm{ppm} \mathrm{N}_{2}$, and $<60 \mathrm{ppm}$ of $\mathrm{H}_{2} \mathrm{O}$.

NOTE: Impurity measurements were made before the start of the weld due to analyzer interference by the $75 \mathrm{He} /$ 25 Ar torch gas. 
Weld Inspections: Visual - good.

Weld Bead Width - 0.085" to 0.110".

Hel i um Leak - $<10 \times 10^{-10} \mathrm{cc} / \mathrm{sec}$ He.

Dye Check - No dye indications using "Tracer Tech", 150 Dye.

The decontamination covers were activated. A Graphite Impact She?] (GIS), S/N 936819-2, is included for shipment to LASL.

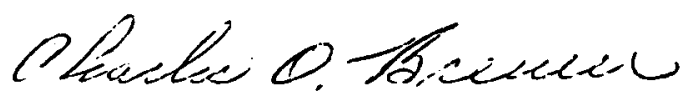

\section{c. 0. Brewer}

COB :eg

Attachment 
MONSANTO RESEARCH CORPORATION

MULTI-100

MOUND IABORATORY

OPERATION SHEET

\begin{tabular}{|c|c|c|c|c|c|}
\hline $\begin{array}{l}\text { MOGAAm } \\
\text { MULTI-HUNDRED }\end{array}$ & IIENT SOURCE & . & 1 of 1 & $\begin{array}{l}\text { manuAt Numbet } \\
\text { MD-70161 }\end{array}$ & $\begin{array}{l}\text { OPEAATON } \\
18\end{array}$ \\
\hline 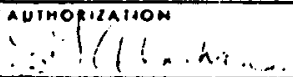 & $\begin{array}{l}\text { Classification } \\
\text { Unclassified }\end{array}$ & $\begin{array}{l}\text { EHCinity } \\
2-20-74\end{array}$ & & $\begin{array}{l}\text { ECNIS| INCORPOR } \\
M 7-C\end{array}$ & \\
\hline
\end{tabular}

MILLER WELDING MACHINE MODEL SR-200-A-LA(S) AIRCRAFTER

Fi: $\because 3(\therefore, i$

ASSEMBLY NAME MIW TRIDIUM SPIIFRE

FIXTURE TYPE OR DRAWING NUMBER MHW SerVo-Tek ROtary Fixture

ROTATIONAL CONTROL TYPE Servo-Tek (370 Setting Ref.)

ACTUAL TIME PER REY. 10 SEC. RUNAING START $\square$ DELAYEDSTART

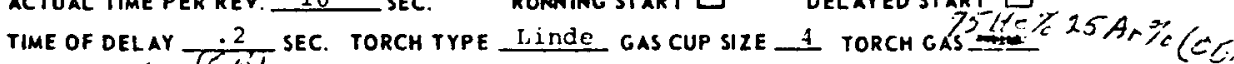
FLOW

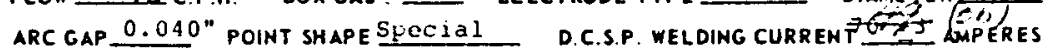
RECORDER $\square$ METER DATER PRESSURE TO THE HEAO HOLO DOWN 12 I US.

IS ISI on loft gage

(t) 17 PSI on right gage

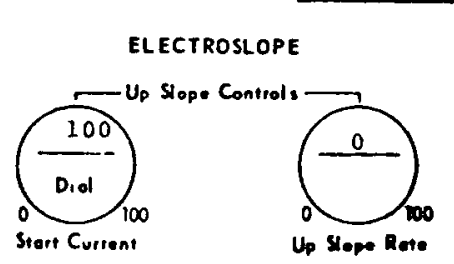

$$
\begin{aligned}
& \vdots \\
& \vdots \\
& \vdots \\
& \vdots \\
& \vdots \\
& \vdots \\
& \vdots \\
& \vdots
\end{aligned}
$$

TIMER CONTROL PANEL (Down)
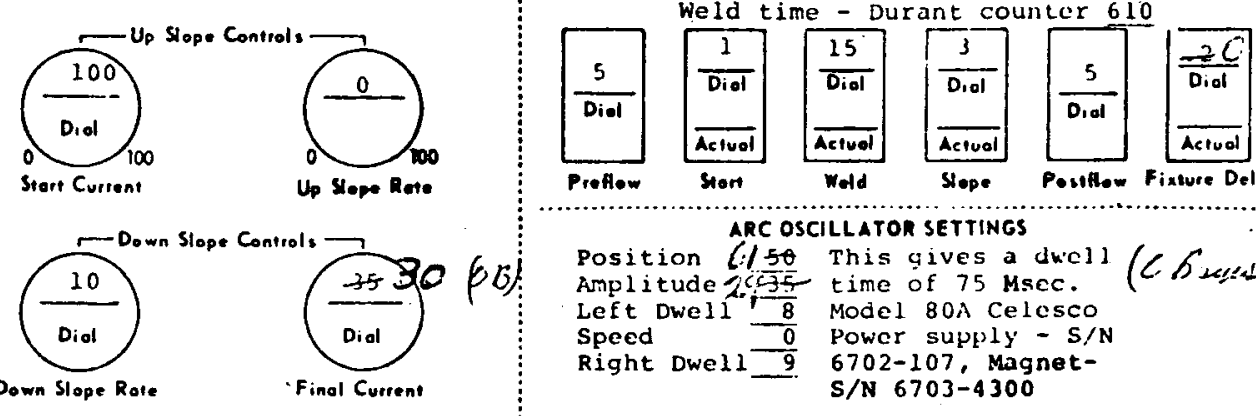

Preflow Sort Weld Slope Postllow Fixture Delay arc oscillatón SETTINGS

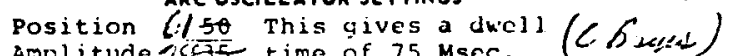

Amplitude Arsf time of $75 \mathrm{Msec}$.

Left Dweli $\frac{8}{8}$ Model $80 \mathrm{~A}$ Celesco

Speed $\quad 0$ Power supply - S/N

Right Dwell 9. 6702-107. Magnet-

S/N 6703-4300
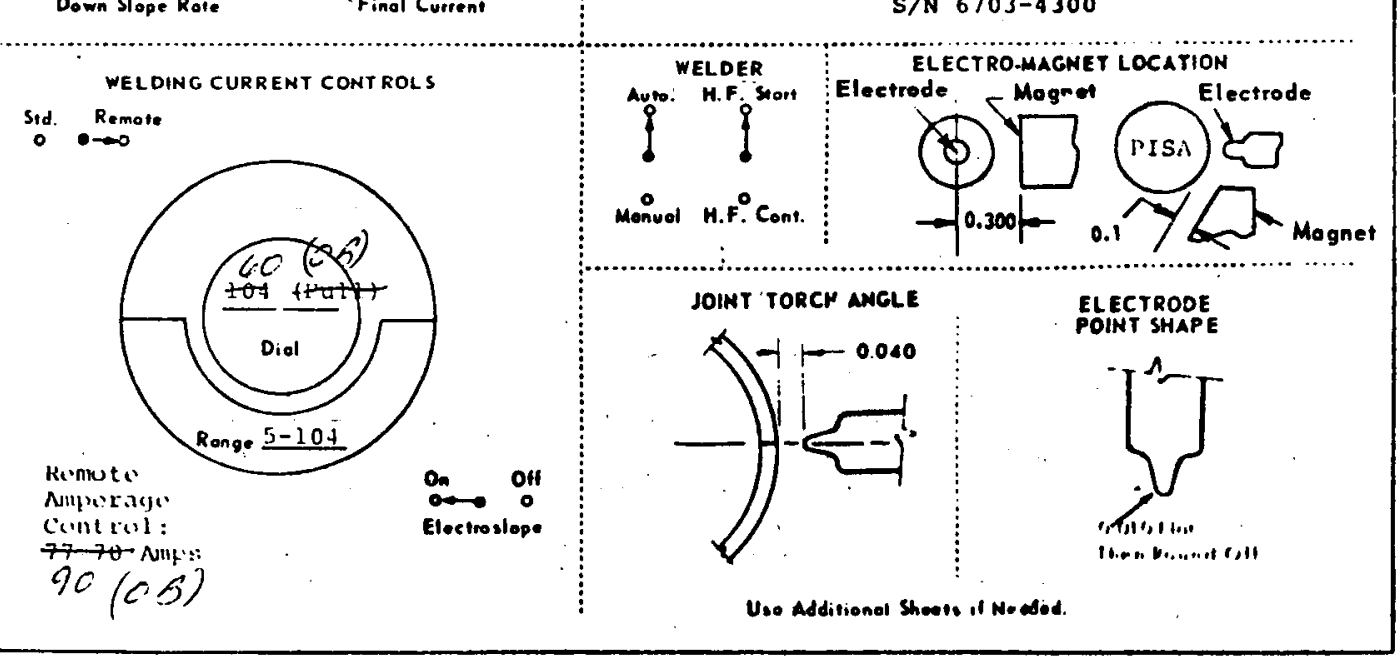

mac m1 128

Issue $2 \cdot 3-18-71$ 


\section{LEAK TEST REPORT}

Name and Model Number of Instrument

11512

Standard S.N. 12559 Standard Value $4.58 \times 10000$

Minimum Detectable Leak Acediponell

TEST TECHNIQUE:

$\square$ Item pressurized at psig for under Helium.

Belium contained in item.

Helium hood.

$\square$ 'Sniffer' probe technique.

$\square$ Helium spray technique.

$\square$ Other

ITEM DESCRIPTION:

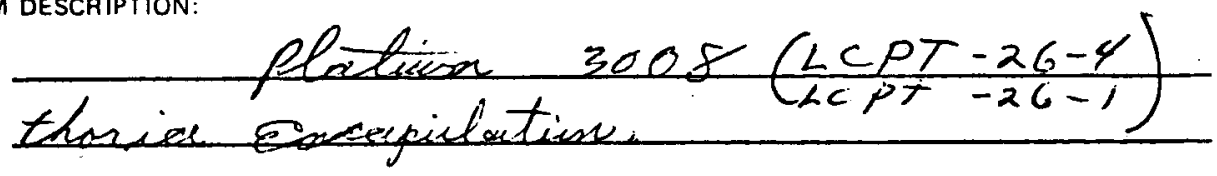
TEST RESULTS:

Item identification

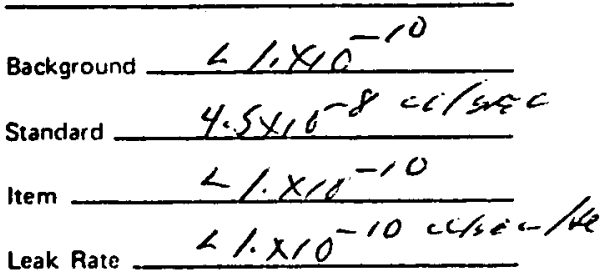

Item identification

Background

Standard

Item

Leak Rate
Item identification

Background

Standard

item

Leak Rate

Item identification

Background

Standard

Item

Leak Rate

COMMENTS

Bv: Oruen Delot

Dats: $12-9.77$

MAC.AIL.3561 (11.76) 
Date $10-4-77$

Distribution:

W. C. Wyder

File:

FLUORESCENT DYE PENETRANT REPORT

Item: PLATINUM HEMISHELLS

LCPT- 26-1 = Not acceptable in accordance with DWG. No. 1-14944 Cracks $0.065^{\prime \prime}$ in from Eq. 0.280" long, (outer surface).

LCPT- 26-4 = Not acceptable in accordance with DWG. No 1-14944. Two cracks on outer surface $0.015^{\prime \prime}$ in length, near dome area.

Listed below are the hemishells that are acceptable in accordance with DWG, No. 1-14944.

LCPT- 26-2 = Acceptable.

LCPT- 26-3 = Acceptable.

Inspected in accordance with AST.E-165

Procedure A-2

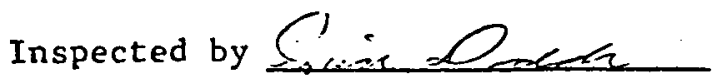


Date: $10-27-77$

Distribution:

D. A. Pawlak

File:

FLUORESCENT DYE PENETRANT REPORT

Items: DECON COVERS (IRIDIUM)

PT-3008 Materia 1

S/N- E2X-4B-1 20 pcs. A11 acceptable on dye penetrant inspection.

Inspected in accordance with ASTME-165

Procedure A-2

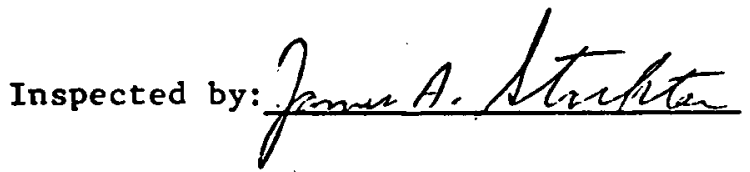


Date $10-\underline{-77}$

Distribut 1:

N. D. Hignite

W. C. Wyder

File:

FLUORESCENT DYE PENETRANT REPORT

Item: DECON COVERS

Material; PT-3008

$\mathrm{S} / \mathrm{N}-\mathrm{E} 2 \mathrm{X}-4 \mathrm{~B}-1$

Accept $=20$

Reject $=20$

Tota $1 \longdiv { 4 0 }$ pes.

The 20.pcs rejected are for cracks in the dome area.

Inspected in accordance with ASTRE-165

Procedure A-2

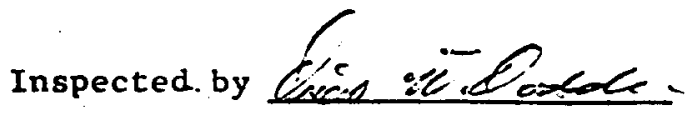


LCPT- 26-1 = Not acceptable in accordance with DWG. No. 1-14944 Cracks $0.065^{\prime \prime}$ in from Eq. 0.280" long, (outer surface).

ICPT- 26-4 = Not acceptable in accordance with DWG. No 1-14944. Two cracks on outer surface $0.015^{\prime \prime}$ in length, near dome area.

Listed below are the hemishells that are acceptable in accordance with DWC, No. 1-14944.

ICPT- 25-2 = Acceptabie.

LCPT- 26-3 = Acceptable.

Inspected in accordance with ASTME-165

Procedure A-2

Inspected by 


\section{RECEIVING REPORT}

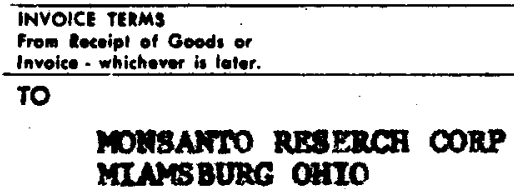

moNBATIO RESERCA CORP

MAMsBurg OHTO

ORDER NO. ROYE.

Burea:

THIS ORDER MUMBER MUST APPEAR ON OUTSIDE OF EACH PACKAGE AND ON ALL SHIPPING PAPELS ANO INVOICES. SHIP TO:

Univorsity of California

Los Alemos Sciontific taboratory

hecoiving Dept.

La Alanes, Naw Mexice 87545

For Onder Informotion phone 505-667.

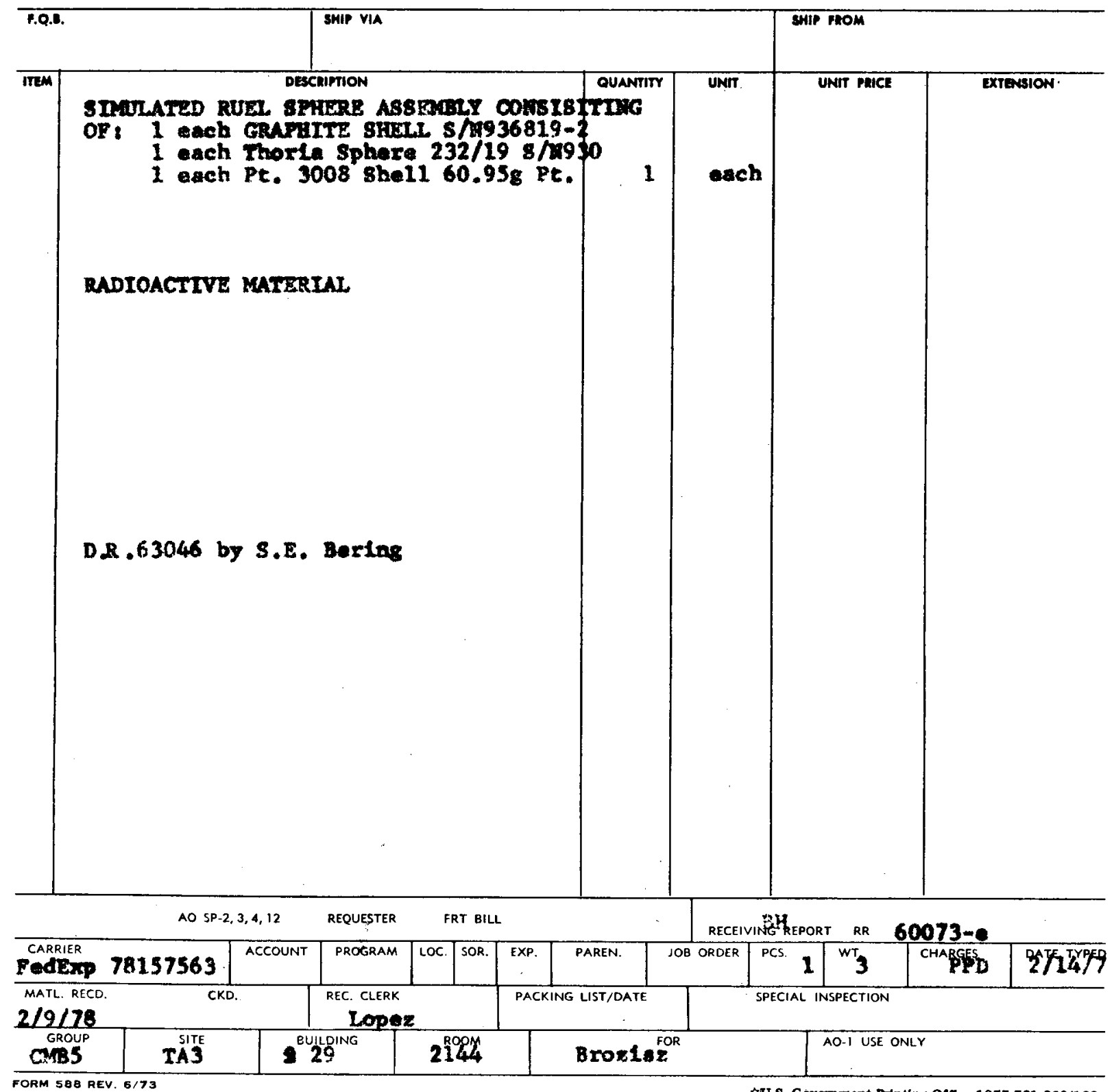

trU.S. Government Printing Offlee-1977-781-260/109 
The following parts are acceptable on dye penetrant inspection. LCPT- 22-2 LCPT- 23-3 LCPT- 25-4

LCPT- 22-3 LCPT- 23-4

LCPT $-23-1 \quad$ LCPT $-24-2$

LCPT - 23-2 LCPT- 25-2

The following hemispheres are not acceptable in accordance with DWG. No. $1-14944$.

LCPT-22-4 = (1) crack 0.020" long inside of part at come area.

LCPT-24-3 = (1) Gouge at inner edge, $0.015^{\prime \prime} \times 0.030^{\prime \prime}$.

LCPT $-24-4=(1)$ indication area $0.005^{\prime \prime} \times 0.005^{\prime \prime}$, located inside $0.250^{\prime \prime}$ from edge. (porous area).

(1) Crack or tear in metral $0.002^{\prime \prime} \times 0.030^{\prime \prime}$, on outer surface $0.600^{\prime \prime}$ from $\in \dot{c} ; 0$.

LCPT-27-2 = (1) Crack 0.004", (outside of part) at dome. area.

LCPT-27-3 = (1) Rough surface located at inner edge, $0.005^{\prime \prime} \times 0.010^{\prime \prime}$.

Inspected in accordance with ASTME-165

Psocecure $A-2$

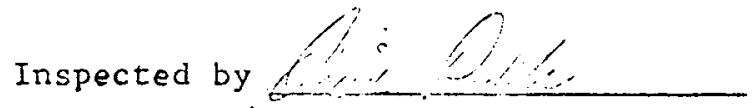

